\title{
SYNOPSIS
}

NeWS

$\bullet$

ANALYSIS

- Practice

Global Health

\section{Reforms mean 25 million Russians lose free health care}

A sweeping package of reforms will see an estimated 25 million Russian pensioners and other government dependants exchange Soviet-era entitlements, including free health services, medicine and public transit, for larger government cheques.

The decision to provide cash in lieu of the entitlements - described by the government as an effort to "monetize" its social commitments - triggered protests in more than 300 cities.

For many, the cash will not compensate for current benefits, especially with $20 \%$ inflation.

Oksana Dmitriyeva, a member of parliament and former social security minister, estimates that "war invalids" in St. Petersburg who now receive monthly benefits valued at between $\$ 50$ and $\$ 160$ per month, will receive only $\$ 100$ under the monetization plan. Disabled children who receive benefits valued at $\$ 58$ to $\$ 133$ per month will get $\$ 50$.

Many of these people are already in dire straits. The government estimates 30 million Russians live below the official subsistence level.

Next month, the Kremlin is expected to disclose how it will implement and finance the reform, which supporters and opponents agree represents the final demise of Soviet-style socialism.

Opposition parliamentarians complained they were given only 24 hours to study the complex 760-page bill when it was tabled in August.

With the reforms, the government estimates payments to veterans and other government dependants will swell from about $\$ 1$ billion to about $\$ 6$ billion next year. The government will achieve dramatic savings, however, by terminating payments to health and welfare service providers.

Health Minister Mikhail Zurabov maintains bigger cheques will increase pensioners' ability to purchase services while reducing pressure on the government to maintain benefits that many eligible people don't use, such as sanatoriums.

A researcher at the Russian Hematology Research Hospital in Moscow is not optimistic. "People have no reason to believe in the government's decisions and guarantees," said Dr. Nikita Efemovich Shklovski-Kordi,"but they guess the money will not [work] as well."

Many Russian hospitals and physicians have anticipated monetization by quietly selling higher quality services to those who can pay. Private healthcare facilities are springing up as the quality of public services plunge.

Although efforts are under way to improve Russian health service delivery through regional centralization schemes, the new laws make the fate of federally supported institutions and health care workers unclear.

Russian health officials have promised to maintain universal access to core services, including maternity care and obstetrics, but critics claim the reforms will drastically reduce medical services for the most vulnerable.

The infant mortality rate in Russia is estimated to be 17 deaths per 1000 live births. Life expectancy at birth is 66 years.

Alexei Surikov, deputy chairman of the Federation of Independent Trade Unions of Russia, which organized national protests against monetization, worries provincial doctors will lose many of the "perks that get them to stay and work in provincial schools and hospitals despite low pay."

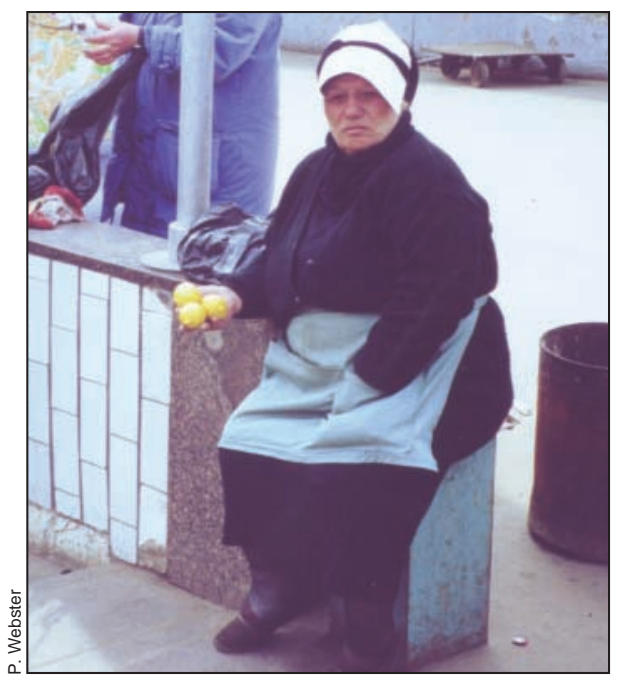

Many Russian pensioners are forced to sell everything from produce to their possessions to survive.

Moscow's Independent Institute for Social Policy says health and welfare reform is urgently needed. Health care analyst, Lilia Ovcharova, says "Russia's system of privileges was never designed to support the poor." The institute estimates that the poorest $10 \%$ of the population receive $4 \%$ of existing benefits, while the richest $10 \%$ receive 20\%. - Paul Webster, Toronto 